\section{Hydrogenolysis of Diaryl Ether C-O Bonds Using a Nickel/Carbon Catalyst}

\section{Gategory}

Polymer-Supported Synthesis

\section{Key words}

hydrogenolysis

ethers

nickel catalysis

bond cleavage

regioselectivity<smiles>CC(C)(C)c1cc(Oc2ccccc2)cc(C(C)(C)C)c1</smiles>
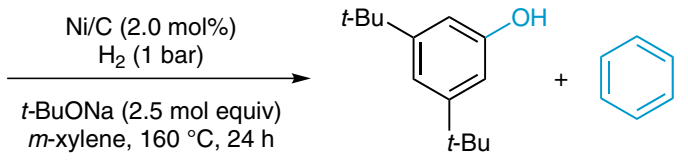

$98 \%$ yield
Significance: The hydrogenolysis of compounds that mimic the diaryl ether moieties in lignin was catalyzed by nickel nanoparticles on carbon $(\mathrm{Ni} / \mathrm{C})$ in the presence of sodium tert-butoxide or potassium hexamethyldisilazide under hydrogen to give the corresponding arenes in $>98 \%$ yield and high selectivity. The hydrogenolysis of ether 1 with $\mathrm{Ni} / \mathrm{C}$ took place without significant aggregation of nickel particles [2-5 nm (1 h); 5-7 nm (24 h)].
Comment: $\left[\mathrm{Ni}(\mathrm{cod})_{2}\right](10 \mathrm{~mol} \%)$ catalyzed the hydrogenolysis of ether 1 at $180{ }^{\circ} \mathrm{C}$ for 24 hours with $20 \%$ conversion; during this period, the nickel particles aggregated from a size of $4-13 \mathrm{~nm}(1 \mathrm{~h})$ to $17-23 \mathrm{~nm}(24 \mathrm{~h})$, as observed by TEM. The authors previously reported that hydrogenolysis of $\mathbf{1}$ occurred in $45 \%$ conversion yield with a ligandfree nickel catalyst at $120{ }^{\circ} \mathrm{C}$ for $48 \mathrm{~h}$ (Science 2011, 332, 439). 